\title{
PERAN KETELADANAN ORANG TUA TERHADAP PEMBENTUKAN KEPRIBADIAN MUSLIM ANAK
}

\author{
MUFAIZIN, M.Pd.I
}

Abstraksi

Secara teoritis, keteladanan merupakan metode yang paling meyakinkan keberhasilannya dalam membentuk kepribadian anak, baik dalam aspek moral, spiritual dan sosial anak. Seperti yang terungkap dalam Maqolah arab; "Lisanul-hal Afsah Min Lisanil Maqal" pengaruh keteladanan melalui tingkah laku itu lebih efektif di banding dengan ungkapan lisan. Anak mengikuti normanorma pada anggota keluarga, baik ayah, ibu maupun kakakkakaknya. Maka orang tua di dalam keluarga harus dan merupakan kewajiban kodrati untuk memperhatikan anakanaknya serta mendidiknya sejak anak itu kecil bahkan sejak anak itu masih dalam kandungan. Jadi tugas orang tua mendidik anaknya terlepas sama sekali dari kedudukan, keahlian atau pengalaman dalam pendidikan yang legal. Keteladanan orang tua yang baik merupakan hal pokok dalam membentuk kepribadian muslim seorang anak. Anak sebagai anggota keluarga diharapkan akan mempunyai kepribadian yang baik. Karena anak yang baik akan menambah kebahagiaan dalam suatu keluarga.

Kata kunci: Keteladanan Orang Tua, Pembentukan Kepribadian Muslim

\section{A. Pendahuluan}

Pendidikan keluarga merupakan letak dasar pembentukan kepribadian anak. Keluarga yang menghadirkan anak di dunia ini, secara kodrat bertugas mendidik anak. Seluruh isi keluarga yang mula-mula mengisi pribadi anak. Dengan cara tidak direncanakan orang tua menanamkam kebiasaan-kebiasaan 
yang diwarisi dari nenek moyang dan pengaruh-pengaruh lain yang diterima anak dari masyarakat. Seorang anak menerima daya peniruannya dengan senang hati, sekalipun kadangkadang anak tidak menyadari apa maksud dan tujuan yang ingin dicapai pendidikan tersebut. Kebiasaan-kebiasaan tertentu yang diinginkan orang tua untuk dapat dilakukan anak ditanamkan benar-benar, sehingga seakanakan tidak boleh tidak dilakukan oleh anak.

Dengan demikian, seorang anak akan membawa kemanapun pengaruh keluarganya, sekalipun seorang anak sudah mulai berfikir lebih jauh lagi. Makin besar seorang anak, pengaruh tersebut semakin luas sampai keseluruh lingkungan hidupnya. Apakah itu daerah pantai, daerah pegunungan, lembah ataupun hutan. Inilah yang membuktikan bahwa dalam perkembangan pribadinya dipengaruhi oleh lingkungannya. Pengaruh itu tidak akan hilang begitu saja sekalipun anak sudah besar dan telah meninggalkan lingkungan tersebut serta sudah berada di lingkungan lain ${ }^{1}$

Peranan orang tua dalam keluarga sangat penting keberadaannya. Orang tua yang bertanggung jawab serta menentukan kemana keluarga itu akan dibawa. Dengan demikian, maka jelaslah betapa mutlaknya kedua orang tua harus bertindak satu tujuan dan bersama-sama dalam mendidik anak-anaknya.

Perbedaan yang sedikit saja akan mengakibatkan anak itu akan selalu ragu-ragu, yang manakah yang harus dianut dari kedua orang tuanya. Anak lahir dalam pembinaan orang tua dan dibesarkan di dalam keluarga. Orang tua tanpa ada yang memerintah langsung memikul tugas sebagai pendidik, baik bersifat sebagai pemelihara, sebagai pengasuh, sebagai pembimbing, sebagai pembina maupun sebagai guru dan

1 Suyono Agus, Lubis Halen, \& Hadi Taufik. 2011. Psikologi Kepribadian. Jakarta: Aksara Baru.8 
pemimpin terhadap anak-anaknya. Ini adalah tugas kodrati tiaptiap manusia. Allah SWT berfirman, yang artinya:

"Hai orang-orang yang beriman, lindungilah dirimu dan keluarga akan api neraka" (Q.S. At-Tahrim:6) ${ }^{2}$.

Anak meniru norma-norma pada anggota keluarga, baik ayah, ibu maupun kakak-kakaknya. Suasana keagamaan dalam keluarga akan berakibat anak tersebut berjiwa agama. Kebiasaan orang tua dan kakak-kakaknya berbuat susila akan membentuk kepribadian yang susila pula pada anak. Pembentukan kebiasaan yang demikian ini menunjukkan bahwa keluarga berperan penting. Karena kebiasaan anak dari kecil akan dilakukan pada masa dewasa tanpa rasa berat, baik secara sadar ataupun lebih-lebih lagi secara tidak sadar. Lebih dari itu terdapat juga pertalian emosional antara anak, orang tua dan kakak-kakaknya. Seorang anak mengidentifikasikan dirinya kepada orang tua dan kakaknya yakni turut berduka cita jika orang tuanya berduka cita dan akan merasa bahagia jika orang tuanya bahagia. Begitulah keadaan saling pengaruh mempengaruhi antara anak dengan orang tuanya dan kakak-kakaknya sampai keadaan emosional.

Anak yang masih dalam keadaan fitrah masih menerima segala pengaruh dan cenderung kepada setiap hal yang tertuju kepadanya. Maka tidaklah heran anak yang lahir dalam keluarga Islam, maka anak tersebut akan cenderung memeluk agama Islam. Anak yang lahir dalam keluarga Kristen, maka anak tersebut cenderung masuk ke agama Kristen. Sebab didikan orang tua terhadap anaknya sesuai dengan yang dipeluk. Seandainya ada keluarga Islam anaknya memeluk agama Kristen atau keluarganya Kristen anaknya memeluk agama Islam, maka kejadian ini mungkin karena faktor lain.

Dewi Aisyah W. mengutip pendapatnya Imam Ghazali mengenai anak sebagai berikut:

2 Departemen Agama RI. 2005. Al-Qur'an dan Terjemahannya.PT.Syamil cipta karya, 560 
Anak itu sifatnya menerima semua yang dilukiskan dan condong kepada semua yang dituju kepadanya. Jika anak itu dibiasakan dan diajari berbuat baik, maka anak itu akan tumbuh atas kebaikan itu dan akan hidup berbahagia di dunia dan akhirat. Tetapi jika dibiasakan begitu saja, maka anak itu akan celaka dan binasa $^{3}$.

Maka yang menjadi ukuran (nilai kemajuan) anak itu terletak pada yang bertanggung jawab yaitu pendidik dan walinya. Pendidikan agama juga berpangkal di dalam keluarga. Sedangkan alam keluarga bagi setiap orang adalah alam pendidikan yang pertama atau pendidikan dasar.

Berdasarkan paparan di atas pembahasan dalam uraian ini dimaksudkan untuk 1) mengetahui peran keteladanan orang tua terhadap kepribadian muslim anak. 2) mengetahui ciri-ciri kepribadian muslim dan faktor-faktor pembentukannya. 3) mengetahui faktor-faktor yang mengokohkan kepribadian muslim dan faktor yang melemahkannya.

\section{B. Peran keteladanan Orang Tua}

Dalam kamus bahasa Indonesia disebutkan bahwa yang dimaksud keteladanan yaitu sesuatu yang patut ditiru. Dalam tarbiyatul awlad fil Islam, Abdullah Nashih Ulwan mengatakan bahwa keteladanan merupakan metode yang paling meyakinkan keberhasilannya dalam membentuk aspek moral, spiritual dan sosial anak ${ }^{4}$.

Imam Ghazali berkata dalam Ihya'-nya:

Anak adalah amanat bagi orang tuanya, hatinya cemerlang bagaikan permata indah yang sunyi dari coretan dan gambar. Ia menerima apa yang terukir pada jiwanya dan cenderung

3 Aisyah W, Dewi. 2001. Sosok Ibu Rumah Tangga Yang Sukses. Surabaya: Putra Belajar.56

$4 \mathrm{lbid}, \mathrm{hlm} 71$ 
terhadap sesuatu yang menarik hatinya. Ia akan tumbuh menjadi anak yang baik dan berbahagia hidupnya di dunia dan di akhirat, dan kedua orang tuanya akan selalu mendapat pahala, begitu juga orang yang mengajarnya. Dan apabila dibiasakan dengan ajaran yang buruk dan tingkah lakunya dibiarkan seperti binatang, maka ia akan menjadi anak yang durhaka yang selalu berbuat kerusakan. Dengan demikian dosanya akan ditanggung oleh orang tuanya sebagai penanggung jawab anak tersebut ${ }^{5}$.

Contoh teladan yang baik merupakan patokan dasar dan pokok dalam pembinaan anak-anak, baik itu dalam membina agama dan akhlak anak. Anak-anak tidak pernah melihat kepada siapapun kecuali pada orang yang berada di sekelilingnya dan tidak meniru perbuatan siapapun kecuali kepada orang yang berada di sekelilingnya. Apabila seorang anak melihat kebaikan maka anak tersebut akan menirunya dan kelak akan menjadi anak yang baik. Begitu pula sebaliknya, jika seorang anak melihat keburukan maka ia pun menirunya dan pada akhirnya ia akan tumbuh menjadi anak yang jahat dimana hal itu akan sukar sekali untuk merubahnya, mengganti atau meluruskannya.

Abdullah Nashih Ulwan berkata dalam bukunya yang berjudul dalam tarbiyatul awlad (pendidikan anak). Contoh teladan dalam pendidikan adalah sarana yang paling berhasil mempengaruhi anak dalam pendidikan akhlak, dalam membentuk kepribadiannya dan keberadaannya di tengah-tengah masyarakat. Hal ini disebabkan keberadaan seorang pendidik adalah sebagai contoh tertinggi dan ideal dalam pandangan anak-anak. Contoh teladan yang baik dalam pandangan anak akan ditiru dalam setiap tingkah lakunya dan akhlaknya secara sadar atau tidak. Tetapi hal itu jelas akan tersimpan dalam jiwanya, perasaannya, baik dalam bentuk tingkah

5 Ibid,69 
laku, ucapan, perasaan dan hal-hal yang tersembunyi lainnya, baik dilihat secara langsung ataupun tidak.

Keteladanan orang tua sangat berguna sekali dan memiliki pengaruh besar dalam mendidik anak yang baik. Sesungguhnya anak apabila terus diarahkan kepada kebaikan, maka jiwanya akan sehat dan bersih karena seorang anak tidak akan mengerti tentang kewajiban dan dasar-dasar pendidikan utama jika tidak diarahkan oleh pendidiknya pada akhlak yang mulia, mengerti tanggung jawab dan mau meneladani perbuatan yang jujur.

Orang tua dalam keluarga sangat diperlukan eksistensinya. Tanpa adanya orang tua suatu keluarga tidak akan sempurna. Orang tua selalu memperhatikan keadaan keluarga juga penting sekali. Bagaimanapun keadaan orang tua adalah sebagai penyetir atau pemegang kendali dalam keluarganya. Karena itu jika keluarga sudah tidak berada pada jalur ini, maka akan resahlah dalam keluarga tersebut. Dan apabila keluarga menginginkan kebahagiaan, maka orang tua harus memperhatikan jalur ini dan mengetahui fungsinya.

Anak sebagai anggota keluarga diharapkan akan mempunyai perilaku yang baik. Karena anak yang baik akan menambah kebahagiaan dalam suatu keluarga. Eksistensi anak dalam keluarga juga diperlukan. Sehingga keluarga tanpa adanya anak akan kurang lengkap pula. Dengan adanya anak dan orang tua saling membutuhkan. Karena itu orang tua harus sadar bahwa anak adalah bagian dari hidupnya. Anak dididik secara intensif sehingga anak menjadi baik.

Karena tugas yang diemban orang tua tidak ringan, maka setiap orang tua yang Islam mempunyai tugas pula dalam menanamkan atau membentuk kepribadan muslim. Kepribadan muslim harus menjadi idola bagi setiap keluarga muslim. Anak yang mempunyai kepribadian muslim akan mudah diarahkan pada kemajuannya. Oleh karena itu orang tua harus tahu dan selalu 
berusaha untuk membentuk kepribadian muslim kepada anakanaknya.

\section{Orang Tua Sebagai Pendidik}

Peran orang tua yang pertama dan utama adalah sebagai pendidik. Sejak kelahirannya, pendidik harus selalu diperankan terhadap anak. Bahkan dalam ajaran Islam pendidikan dikenalkan sebelum kelahiran anak, yang disebut dengan pendidikan pranatal. Pendidikan ini diberikan kepada anak yang masih dalam kandungan tersebut. Melakukan perbuatan baik ini diharapkan anak akan

merasakan dampak psikologinya.

Sehubungan dengan peran orang tua sebagai pendidik Muhammad Athiyah Al-Abrasyi mengatakan beberapa pengaruhnya terhadap anak terutama :

a) Dalam gaya dan bicara, anak mulai berbicara dengan bahasa ibu, jika isi pembicaraan itu baik, akan menjadi baik pula pembicaraan anak, karena masa anak adalah masa meniru tentang apa yang bisa didengar dan dilihat.

b) Dalam tingkah laku, adab sopan santun yang baik dalam keluarga akan memberikan corak terhadap tingkah laku anak selanjutnya ${ }^{6}$.

Sistem di atas mengharapkan orang tua hendaknya selalu membiasakan diri berbahasa yang baik. Bahasa akan secara tidak sadar mencetak anak untuk berbicara, apabila pembicaraan itu baik, maka anak akan tercetak berbahasa dengan baik, sebaliknya jika pembicaraan itu tidak baik, berakibat tidak baik pula pada diri anak. Karena peniruan anak sangat sensitif, maka sekali saja anak mendengar pembicaraan yang tidak baik, anak akan

6 Yusuf Bakir, Pasmawi. 1993. Pembinaan Kehidupan Beragama Islam Pada Anak.Semarang:Dina Utama. 12 
menirukannya. Sedangkan yang kedua perilaku orang tua harus sopan dan santun. Tidak berbeda dengan pertama karena sensitifnya peniruan, orang tua harus hati-hati dalam setiap tingkah lakunya. Hubungan antara suami isteri harus mencerminkan kehidupan yang sakinah sebagaimana yang diajarkan Islam.

Pembiasaan anak pada situasi keagamaan yang baik, membawa dampak yang baik pula pada perkembangan jiwanya. Jiwa yang semula telah beragama atau mempunyai fitrah beragama akan senantiasa ada pada jalur ini apabila diisi dengan nilai-nilai agama, oleh karena seorang anak yang dilahirkan dalam keluarga yang taat beragama, berakhlak mulia maka dimasa dewasanya nanti akan menjadi manusia yang taat beragama pula, karena nilainilai agama telah terserap dalam jiwanya ${ }^{7}$.

Peran orang tua dalam mendidik keagamaan ini sangat besar sekali. Karena pada dasarnya keluarga merupakan lembaga yang pertama dan utama. Nilai-nilai religius harus menjadi sandaran utama bagi setiap orang tua. Orang tualah yang berkewajiban pertama dalam mencetak anak. Pada dimensi religius ini, pendidikan yang lain bersifat lanjutan. Dalam hal ini M. Ngalim Purwanto menyatakan:

Dalam mendidik anak itu, sekolah sifatnya melanjutkan pendidikan anak-anak yang telah dilakukan orang tua di rumah. Berhasil baik atau tidaknya pendidikan di sekolah bergantung dan dipengaruhi oleh pendidikan di dalam keluarga. Pendidikan keluarga adalah fundamenatal dasar dari pendidikan anak selanjutnya. Hasil-hasil pendidikan yang diperoleh anak dalam keluarga menentukan pendidikan anak itu selanjutnya, baik di sekolah maupun di masyarakat ${ }^{8}$.

7 Ibid.

8 Ngalim Purwanto. 2000. Ilmu Pendidikan Teoritis Dan Praktis. Bandung: Remaja Rosda Karya. 85-86 
Beberapa hal di atas apabila dilakukan orang tua, maka kebaikan dari keluarga tersebut tidak hanya berekses kepada keluarga itu sendiri, akan tetapi lebih jauh lagi pada masyarakat.

2. Hubungan Orang Tua Dengan Anak

Setiap anak yang lahir mempunyai hak yang dibebankan pada orang tua. Orang tua harus memenuhi hak-hak tersebut. Adapun hak-hak anak terhadap orang tua secara terperinci adalah sebagai berikut:

a. Hak untuk mendapatkan perawatan dan perlindungan.

b. Hak untuk mendapatkan susuan dan makanan.

c. Hak untuk mendapatkan kasih sayang.

d. Hak untuk mendapatkan asuhan dan nafkah.

e. Hak untuk dipenuhi semua kebutuhannya baik kebutuhan fisik, psikis, maupun kebutuhan yang bersifat biologis lainnya ${ }^{9}$.

Demikian merupakan rentetan hak anak. Ini merupakan kewajiban orang tua terhadap anaknya. Setiap anak harus menerima hak-hak ini. Orang tualah dalam hal ini yang seharusnya memenuhinya, sehingga hubungan mereka secara alamiah bisa tercapai.

Namun demikian yang dibebani kewajiban tidak orang tua, tetapi anak di samping memperoleh hak juga menanggung kewajiban. Anak dalam hubungan dengan orang tua harus baik. Anak harus menghormati orang tua. Secara moral anak mempunyai hutang yang besar kepada orang tua. Karena orang tua pada umumnya secara tulus menuangkan kasih dan sayangnya. Juga mendidik anak pada jalan yang baik. Pengorbanan semacam ini tidak menuntut anak untuk membalasnya secara materi. Namun demikian anak hanya

9 Husain Toha, Khoiriyah. 1992. Konsep Ibu Teladan. Surabaya: Risalah Gusti.100 
dituntut untuk mengerti dan menyadari sehingga dapat berlaku baik terhadap orang tuanya.

Menurut pandangan Islam anak dituntut supaya senantiasa berlaku baik terhadap orang tua. Anak diwajibkan bersikap lemah lembut terhadap orang tua. Kewajiban ini tidak hanya pada tingkah lakunya, pembicaraannya apabila kasar dilarang oleh Islam. Sehingga dalam pandangan Islam berkata "ah" saja tidak boleh apalagi lebih dari pada itu sangat dilarang oleh Islam.

Tidak jarang kita jumpai dalam kehidupan anak yang tidak sopan terhadap orang tua. Anak selalu membantah yang diperintahkan orang tuanya, dia juga selalu disia-siakan.

Sikap orang tua yang tidak memperhatikan dan tidak ada kasih sayang adalah salah. Seharusnya orang tua sebagai mediator anak supaya anak lebih baik. Karena pada dasarnya;

Orang tua sebagai pusat kehidupan rohani anak dan sebagai penyebab berkenalnya dengan alam luar, maka setiap reaksi emosi anak, dan pemikirannya di kemudian hari, terpengaruh oleh oleh sikap anak terhadap orang tuanya dipermulaan hidupnya dahulu ${ }^{10}$.

Demikian jauh peranan orang tua karenanya orang tua yang tidak memperhatikan anaknya dapat dikatakan pengingkaran terhadap kodratnya. Karena secara kodrati orang tua selalu menginginkan anaknya supaya baik, peran orang tua tidak bisa diabaikan.

3. Pentingnya Hubungan Baik Antara Orang Tua Dan Anak

Kehidupan mawaddah warahmah adalah dambaan setiap keluarga muslim. Dambaan ini adalah wajar karena setiap insan yang melangkah kejenjang rumah tangga pasti

10 Zakiyah drajat.2003. Ilmu Jiwa Agama. Jakarta: Bulan Bintang,hlm 96 
menginginkan keberhasilan yang pada akhirnya dengan keberhasilan tersebut keluarga akan bahagia.

Menurut ajaran Islam dalam keluarga harus ditumbuhkan rasa kasih sayang. Dengan ini keluarga selalu menyuguhkan kebaikan anggota keluarga. Keluarga yang berbahagia akan berbeda dengan keluarga berantakan. Secara psikologis keluarga yang bahagia akan membuahkan ketentraman dalam setiap individu yang ada pada keluarga tersebut. Di luar rumah keluarga bahagia akan dapat memberi warna tersendiri pada setiap penampilan anggota keluarga. Lebih jelas dari suasana keluarga yang bahagia dalam lingkungan rumah akan tercipta suasana yang asri. Penciptaan lingkungan rumah yang asri dalam pandangan Islam sangat dianjurkan. Islam menyatakan supaya setiap keluarga muslim membuat suasana rumah adalah sebagai surga di dunia. Suasana semacam ini tidak akan tercipta manakala keluarga tidak bahagia. Hubungan antara anak tidak harmonis tidak akan tercipta suasana rumah yang demikian. Oleh karena itu usaha untuk menciptakan suasana bahagia hukumnya wajib bagi setiap muslim.

C. Ciri-ciri kepribadian muslim dan faktor pembentukannya

Sebelum lebih jauh pembahasan tentang pengertian kepribadian muslim, ada baiknya kita ketahui terlebih dahulu kepribadian secara umum. Kalau ditinjau dari sudut psikologis kepribadian merupakan "sejumlah sifat-sifat tertentu yang membedakan seseorang dari orang lain" ${ }^{11}$.

Atas dasar pengertian di atas, kepribadian merupakan titik perbedaan antara orang yang satu dengan orang lain melalui pandangan sifatnya. Sifat-sifat dari seseorang merupakan

11 Ja'far, Muhammadiyah. 1982. Beberapa Aspek Pendidikan Islam.

Surabaya: AlIkhlas.47 
karakteristik kepribadiannya. Dengan demikian menurut pandangan ini kepribadian itu identik dengan sifat yang menempel pada seseorang sebagai ciri khas penampilan dalam hidupnya.

Adapun secara definitif kepribadian adalah dinamika dari sistem-sistem dalam individu yang turut menentukan cara-caranya yang unik dalam menyesuaikan dirinya dengan lingkungannya ${ }^{12}$.

Adapun pandangan lain ada yang menyatakan bahwa:

"Personality is the entire mental organization of human being at any stage of his development. It embraces every phase of human character, intelect, temperament, skill, morality and every attitude that has been built up in the course of one's life" Artinya: kepribadian adalah segenap organisasi mental dari seseorag yang terdapat dalam sepanjang perkembangannya. Ia meliputi tiap-tiap fase seseorang yaitu karakter, intelek, temperamen, kecakapan, moralitas dan tiap-tiap sikap yang dihasilkan dalam meniti perjalanan hidupnya ${ }^{13}$.

Sedangkan G.W Allport berpendapat kepribadian dinyatakan "the dynamic organization within the individual of those psychopsysical, that determines his unique adjusment to his environment". Artinya: Kepribadian adalah suatu organisasi aspekaspek kejiwaan-kejasmanian yang dinamis pada diri seseorang yang menyebabkan ia mampu menyesuaikan diri dengan lingkungannya

135

Menurut pengertian di atas kepribadian adalah ekspresi manusia secara total. Kepribadian merupakan totalitas manusia, yaitu tidak hanya pada aspek fisik saja tetapi juga psikisnya.

12 Zuhairini dkk.2010.Filsafat Pendidikan Islam. Jakarta: Bumi Aksara.187

13 Suryapratondo, Suparlan. 1993. Ilmu Jiwa Kepribadian. Jakarta: Paryu Barokah.110 ${ }^{135}$ Suyono Agus, Lubis Halen, dan Hadi Taufik. 2011. Psikologi Kepribadian. Jakarta:

Aksara Baru.11 
Pemaduan antara keduanya yang akhirnya muncul kepribadian manusia.

Kepribadian ada juga yang menyatakan suatu yang memberikan arahan jelas atas petunjuk pada seseorang untuk dapat berbuat pada lingkungannya. Sebagaimana yang diungkapkan Cattel bahwa "Personality is that which permits a prediction of what a person will do I a given situation".

Artinya: Kepribadian adalah suatu yang memberikan sasaran (arah) dari mana orang akan berbuat terhadap lingkungan yang tersedia ${ }^{14}$.

Dari beberapa pendapat di atas, walaupun ada perbedaan sudut pandang akan tetapi arah tujuannya adalah sama yaitu kepribadian merupakan:

a. Dua aspek jasmani dan rohani

b. Mempunyai karakteristik tersendiri antara individu yang satu dengan yang lainnya, sehingga terlihat adanya perbedaan.

c. Pada dasarnya kepribadian merupakan kegiatan yang kompleks sebagai totalitas yang dimiliki oleh setiap orang.

Setelah kita ketahui kepribadian pada umumnya, sekarang kita mengkaji tentang kepribadian muslim. Ahmad D. Marimba menyatakan bahwa:

Kepribadian muslim adalah kepribadian yang seluruh aspekaspek yakni baik tingkah laku luarnya kegiatan-kegiatan jiwanya, maupun falsafah hidupnya dan kepercayaannya menunjukkan pengabdian kepada Tuhan, penyerahan diri kepadaNya ${ }^{15}$.

Statemen yang diungkapkan Ahmad D. Marimba di atas, kepribadian muslim merupakan kepribadian yang dihiasi dengan

14 Suryabrata, Sumadi. 2006. Psikologi Kepribadian. Jakarta: Rajawali pres .297

15 D, Marimba, Ahmad. 1982. Pengantar Filsafat Pendidikan Islam. Bandung: PT. AlMa'arif.. 10 
keimanan, karena kepribadian adalah sikap secara totalitas manusia, maka kepribadian muslim berarti semua sikap, tingkah laku, sikap yang dihasilkan dari manifestasi kegiatan jasmaniyah dan rohaniyah bersandar pada ajaran-ajaran Islam. Norma yang menghiasi kepribadian muslim ialah dari pengetahuannya tentang Islam.

Orang yang berkepribadian muslim mempunyai keimanan yang mantap. Dia juga melaksanakan syari'at Islam dengan tekun dan benar. Di samping itu segala perbuatannya dihiasi dengan nilainilai Islam.

\section{Ciri-ciri Kepribadian Muslim}

Dari pengertian kepribadian muslim di atas, dapat diambil konklusi bahwa kepribadian muslim mempunyai beberapa karakteristik tersebut adalah sebagai berikut: a) beriman yang tangguh, b) beramal sholeh, c) berakhlak mulia. a. Beriman yang tangguh

Iman berarti percaya. Dengan demikian beriman yang dikehendaki oleh Islam adalah mempercayai segala yang diajarkan oleh Islam. Keimanan ini merupakan pokok ajaran Islam, atau dengan kata lain keimanan merupakan fondasi ajaran Islam. Sebelum umat Islam melangkah lebih jauh maka keimanan dalam dirinya harus ditata terlebih dahulu. Iman dalam diri insan setiap muslim harus mendapat prioritas pertama dan utama. Karena keimanan ini adalah penyangga kuat, maka setiap Muslim harus berusaha memantapkannya.

Iman sebagai titik pokok ajaran Islam memberikan beberapa keyakinan dan pengajaran kepada umat Islam, yaitu:

1) Iman mengajarkan dan memberikan keyakinan dan kepercayaan kepada manusia bahwa Tuhan itu adalah 
Esa dan bersifat dengan segala sifat kesempurnaanNya.

2) Iman mengajarkan dan memberikan keyakinan kepada manusia bahwa manusia itu asalnya adalah satu

3) Iman mengajarkan dan memberikan keyakinan kepada manusia bahwa segala sikap dan tindakannya selalu diawasi an dicatat dengan cermat

4) Iman mengajarkan dan memberikan keyakinan kepada manusia bahwa segala kreativitas ia hanya merencanakan dan bekerja. Adapun hasil dan tindakannya Tuhan yang menentukan.

5) Iman mengajarkan dan memberikan keyakinan kepada manusia bahwa hidupnya akan berlangsung sampai hari kiamat ${ }^{16}$.

Dalam ajaran Islam ada beberapa rangkaian keimanan yang tersusun berdasarkan ayat berikut: yang Artinya:

"Wahai orang-orang yang beriman, tetaplah beriman kepada Allah dan Rosulnya dan kepada kitab yang telah Allah turunkan kepada Rasul-Nya, serta kitab Allah yang diturunkan sebelumnya. Barang siapa yang kafir kepada Allah, malaikat-malaikat-Nya, kitab-kitab-Nya, Rasulrasul-Nya dan hari kemudian, maka sesungguhnya itu telah sesat sejauh-jauhnya ${ }^{17}$.

Dari ayat di atas, dapat disimpulkan ada beberapa keimanan yang harus diyakini setiap umat Islam. Adapun keimanan-keimanan tersebut adalah sebagai berikut:

1) Iman kepada Allah SWT

2) Iman kepada malaikat-malaikat Allah

16 Zaini, Shahriman.1996. Nilai-nilai Iman. Surabaya: Usaha Nasional.127

17 Departemen Agama RI. 2005. Al-Qur'an dan Terjemahannya.PT.Syamil cipta karya, 
3) Iman kepada kitab-kitab Allah

4) Iman kepada rasul-rasul Allah

5) Iman kepada hari kiamat

6) Iman kepada qodho' dan qodar

Enam kriteria di atas setiap umat Islam dituntut mempercayai secara integral, yaitu rangkaian iman tersebut tidak boleh dipisah-pisahkan. Semua saling terkait dan saling mengisi. rumusan tentang keimanan di atas dalam ajaran Islam disebut dengan rukun iman.

b. Beramal sholeh

Setiap orang yang berkepribadian muslim tentunya mempunyai komitmen yang besar terhadap ajaran Islam. Dalam ajaran Islam ada lima pokok yang harus dijalankan bagi setiap muslim sesuai dengan ketentuan. Adapun lima hal tersebut adalah sebagai berikut:

1) Membaca kalimat syahadat

2) Menjalankan sholat

3) Membayar zakat

4) Menjalankan puasa Ramadlan

5) Menunaikan ibadah haji

Lima pokok ajaran ini yang disebut dengan rukun Islam. Yang pertama adalah syahadat. Kalimat ini merupakan langkah awal bagi mereka yang beragama Islam. Syahadat juga sebagai ikrar yang momumental. Karena monumentalnya menurut ajaran Islam kalimat ini 
mempunyai nilai yang tinggi di hadapan Allah. Pernyataan syahadat ini merupakan pernyataan yang mengandung konsekuensi. Dalam arti apabila ikrar suci ini sudah dilaksanakan berarti harus siap melaksanakan segala ajaran yang ada di dalamnya. Karena isi ikrar ini menyatakan bahwa tidak ada satu Tuhan pun yang ada di seantero dunia ini

c. Berakhlak mulia.

Akhlak yang mulia merupakan hiasan setiap muslim. Maka bagi setiap muslim berakhlak yang mulia harus menjadi idolanya. hal ini selaras dengan misi dan terutusnya rasulullah ke bumi ini, sebagaimana sabdanya:

"Bahwasanya aku diutus Allah hanya untuk menyempurnakan akhlak budi pekerti" (HR. Ahmad) ${ }^{18}$.

Seseorang yang disetir dengan akhlak yang mulia dalam hidupnya akan selalu mempunyai arah dan tujuan yang baik. Setiap hendak melakukan kegiatan dipikir terlebih dahulu apakah perbuatan tersebut berakibat baik atau sebaliknya. Kondisi ini akan membawa dampak baik kepada dirinya sendiri maupun orang lain.

Akhlak yang mulia akhlak yang bersumber ajaran Islam, yang telah tertuang dalam al-Qur'an dan Hadist, dimana keduanya menjadi standart dalam segala perbuatan. Di samping itu Nabi Muhammad merupakan sentral moral atau akhlak yang baik, sehingga Nabi Muhammad bagi seluruh alam ini menjadi suri tauladan yang baik (uswatun hasanah).

2. Faktor-faktor Pembentukan Kepribadian Muslim

Kepribadian muslim tidak bisa terbentuk dengan sendirinya tanpa adanya proses. Dengan proses kepribadian

18 Ahmad bin hanbal, "Al-masnad",Darul-kutub-ilmiyah.Beirut.Lebanon,2005.Juz.1,312 
dapat berkembang dengan baik, karena kepribadian sudah ada sejak kelahiran atau setiap manusia sudah ada fitrah yang dibawanya sejak lahir. Oleh karena itu ada dua faktor yang saling mendukung dalam pembentukan kepribadian muslim, yaitu faktor pembawaan dan lingkungan. a. Faktor pembawaan

Pembawaan atau biasa disebut dengan fitrah pasti dimiliki oleh setiap manusia. Fitrah selalu menempel pada setiap langkahnya. Oleh karena itu ini dapat mendukung pembentukan kepribadian secara optimal. Fitrah atau biasa disebut dengan potensi inilah yang diharapkan menjadi penopang pembentukan kepribadian. Para ahli psikologi berbeda pendapat dalam memandang pembawaan ini. Yang terbagi dalam aliran-aliran yaitu nativisme, empirisme, konvergensi.

1) Aliran Nativisme dengan tokohnya Schopen Hower. Aliran ini memandanng bahwa "nasib anak itu sebagian besar berpusat pada pembawaannya, sedangkan pengaruh lingkungan hidupnya hanya sedikit saja" ${ }^{19}$.

Dengan demikian berdasarkan aliran ini kepribadian muslim setiap orang telah ada padanya dan hal ini yang paling dominan dalam pembentukannya.

2) Aliran empiris, dengan tokohnya John Lock, dia berpendapat bahwa perkembangan anak itu sepenuhnya tergantung pada faktor lingkungan, sedangkan bakat tidak ada pengaruhnya, karena anak itu lahir dalam keadaan suci, bersih seperti kertas

19 Kasiram.1990. Ilmu Jiwa Perkembangan, Surabaya:Usaha Nasional.27 
putih dan belum ditulisi sehingga dapat ditulisi menurut kehendak penulisnya ${ }^{20}$.

Menurut aliran ini yang paling dominan membentuk kepribadian ini adalah lingkungan. Jadi inilah yang banyak memberi arah kepribadian tersebut kepribadian muslim.

3) Aliran konvergensi dengan tokohnya Wiliam Stern. Menurut pendapatnya "Perkembangan itu adalah hasil kerja sama dua faktor yaitu pembawaan dan lingkungan, faktor dasar dan faktor ajar" (M. Kasiram, 1983: 29).

Aliran ini nampak lebih fleksibel dibandingkan dengan pendapat di atasnya kalau diperhatikan dari pendapatnya dari pembawaan dan lingkungan mempunyai andil yang sama keduanya saling mempengaruhi. Pembawaan atau potensi ada tanpa didukung lingkungan yang memadahi sulit berkembang dengan baik. Demikian pula sebaliknya lingkungan yang baik kalau potensi tidak ada, maka perkembanganya akan terlambat.

b. Faktor lingkungan

Sebagaimana pendapat aliran di atas, lingkungan mempunyai peranan yang besar dalam pembentukan kepribadian. Namun demikian aliran konvergensi menyatakan tidak mutlak lingkungan yang paling dominan dalam membentuk kepribadian.

1) Lingkungan keluarga

Lingkungan keluarga merupakan faktor yang pertama dikenal oleh anak. Oleh karena itu "orang tua adalah pembina pribadi yang pertama dalam hidup

20 lbid. 28 
anak“ ${ }^{21}$. Dengan demikian orang tua sangat diperlukan dalam pembinaan ini. Untuk membentuk kepribadian muslim secara maksimal perlu perhatian hal-hal sebagai berikut :

a) Kesediaan orang tua menerima anak sebagai keluarga yang bahagia.

b) Pertengkaran dan perselisihan faham antara orang tua supaya tidak terjadi di hadapan anak.

c) Penyesuaian yang baik antara ayah dan ibu.

d) Adanya sikap demokratis yang memungkinkan setiap orang keluarga mengikuti sendiri sejauh tidak merugikan dan merintangi kesejahteraan orang lain.

e) Penerimaan tetangga terhadap dirinya ${ }^{22}$.

2) Lingkungan sekolah

Lingkungan sekolah adalah lingkungan formal. Sekolah sebagai lingkungan sangat teratur dalam membentuk kepribadian. Tidak jarang kepribadian yang berkembang dengan baik karena pengaruh lingkungan sekolah ini. Maka lingkungan sekolah yang baik sangat diperlukan dalam membentuk kepribadian muslim. Menurut A. Singit bahwa yang penting bagi pendidikan agama adalah soal etika sosial; guru harus memahami rasa susila anak untuk dikembangkan karena dengan tidak mengembangkan rasa susila anak pendidikan agama tidak akan berhasil (Arifin, 1986 :96).

Dair sekolah ini banyak diperoleh informasi tentang norma-norma kebaikan. Apalagi sekolah

21 Zakiah drajat.Opcit.71

22 lbid.72 
yang banyak memberi pelajaran-pelajaran agama. Disitulah anak mendapat pelajaran dengan seksama juga terorganisir. Melalui belajar yang teratur bisa menambah wawasan tentang kebaikan.

Di samping pembentukan norma, di sekolah diperoleh pengetahuan yang lain. Norma dapat diperoleh melalui belajar juga pengaruh dari temantemannya. Karena pentingnya hal ini maka seharusnya dalam memilih teman adalah yang baik.

3) Lingkungan masyarakat

Masyarakat sebagai lingkungan yang penting dalam membentuk kepribadian muslim. Dalam masyarakat dapat diperoleh berbagai macam norma yang berkembang. Norma-norma tersebut ada yang positif ada pula yang negatif karena itu kita dituntut untuk sepandaipandainya dapat memilih yang positif. Lingkungan masyarakat adalah lingkungan yang mutlak kita jalani, karena semua orang tidak bisa menghindari hal itu.

D. Hal-hal Yang Dapat Memperkokoh Kepribadian Muslim dan Yang Dapat Melemahkannya.

Walau setiap orang sudah mempunyai potensi kepribadian muslim, namun masih perlu pendukung untuk memperkokoh kepribadian tersebut agar lebih berkembang dan tidak sebaliknya. Ada beberapa hal yang dapat memperkokoh kepribadian muslim yaitu "bertujuan, berkeinginan bekerja, rasa wajib, pengaruh agama dan iman serta pengaruh sembahyang".

1. Bertujuan 
Tujuan adalah arah yang dituju oleh seseorang untuk mencapai sesuatu. Setiap langkah seseorang harus ada tujuan agar yang dilaksanakan jelas maksudnya. Dan dengan mempunyai tujuan dilaksanakan secara intensif, maka keberhasilan akan lebih dekat.

2. Keinginan bekerja

Etos kerja sangat perlu ditingkatkan setiap orang yang hendak atau berkeinginan mencapai keberhasilan. Selanjutnya keinginan bekerja akan menambah:

a. Tingginya mutu pekerjaan.

b. Menggiatkan dan memajukan, yang mengakibatkan tumbuhnya kegembiraan.

c. Mendorong kita agar lebih kuat melaksanakan, menimbulkan inspirasi untuk merombak segala pagar kesulitan ${ }^{23}$.

3. Rasa wajib

Melaksanakan kewajiban tentu berbeda dengan melaksanakan sesuatu hal yang sunat hukumnya. Karena kewajiban menuntut untuk dilaksanakannya jika tidak dilaksanakannya akan membawa akibat. Contohnya umat Islam wajib melaksanakan puasa Romadhon, dengan mempunyai rasa wajib, maka tidak akan mudah untuk meninggalkannya.

4. Pengaruh sholat

Setiap agama mempunyai cara tersendiri dalam sembahyang. Sedangkan bersholat sendiri merupakan aktifitas ritual yang membuat perilakunya untuk pasrah dan ikhlas. Isi dari setiap sholat adalah berupa do'a-do'a yang dikemas dengan cara tertentu. Sehingga dengan sholat mempunyai

23 Hamka. 1989. Menjadi Pribadi muslim sejati. Jakarta: Bulan Bintang.89 
pengaruh kepada pelakunya yaitu akan mempunyai sikap yang luhur.

5. Pengaruh agama dan iman

Agama biasanya selalu mengajak pada pemeluknya selalu berbuat baik. Dengan keterpautan terhadap agama yang tinggi, maka akan membuat pemeluknya selalu rela. Hal ini juga termasuk agama Islam, apabila agama Islam telah tertanam pada setiap insan maka kebaikanlah yang selalu ada padanya.

Dalam agama juga mengajarkan keimanan, begitu pula dengan agama Islam. Islam mengajarkan bagaimana seharusnya ditumbuhkan. Dengan keimanan yang mantap membuat pemeluknya juga selalu dalam kebaikan.

Dalam pembentukannya ada beberapa yang perlu diantisipasi karena dapat menghalangi pembentukan kepribadian muslim. Adapun hal-hal tersebut adalah sebagai berikut yaitu "menjadi bayang-bayang orang lain, ikatan adat lama, pusaka (usang), budak kitab, tak tentu arah dan benalu" ${ }^{24}$.

1. Menjadi bayang-bayang orang lain

Menjadi bayang-bayang orang lain berarti tidak mempunyai sikap mandiri, dia selalu mengikor pada orang lain. Sikap ini tidak baik pengaruhnya terhadap pembentukan kepribadian muslim, pribadi yang demikian akan sulit berkembang dia selalu statis dan sulit mencapai keberhasilan.

2. Ikatan adat lama, pusaka (usang)

Tidak jarang orang yang sulit meninggalkan adat istiadat walaupun berakibat tidak baik. Adat dan pusaka sering menjerat dengan menghalangi perkembangan kepribadian muslim, juga bisa berakibat merusak dan membahayakan.

24 lbid.115 
Oleh karena itu hal semacam ini perlu diantisipasi agar pembentukan muslim dapat sebaik-baiknya.

\section{Budak Kitab}

Kitab banyak pula yang membawa bagi pembacanya. Namun tidak sedikit pula kitab yang mempunyai pengaruh tidak baik bagi pembacanya. Pemikiran-pemikiran tidak baik yang tertuang dalam kitab tersebut dapat mempengaruhi pembentukan kepribadian muslim. Oleh karena itu dalam membaca buku perlu diseleksi mana buku yang baik dan mana buku yang tidak baik.

4. Tak tentu arah

Arah dan tujuan diperlukan untuk mencapai keberhasilan, tanpa adanya hal ini sulit akan bisa tercapai. Karena itu suatu perbuatan yang tidak tentu akan menjadi kabur dan sulit berkembang.

5. Benalu

Benalu adalah salah satu sikap yang dapat meracuni perkembangan kepribadian. Sikap ini tidak mempunyai pendirian yang pasti sehingga perilakunya mudah terjerumus pada hal-hal yang dapat merugikannya.

E. Penutup

Dari apa yang telah dipaparkan di atas maka dapat ditarik beberapa kesimpulan sebagai berikut:

Keteladanan orang tua sangat besar peranannya dalam pembentukan kepribadian bagi anak-anak, karena dilingkungan keluargalah anak-anak pertama kali dikenalkan dan menerima pendidikan yang dapat mempengaruhi perkembangan anak selanjutnya.

Adapun peran keteladanan orang tua antara lain: 1) sebagai pendidik baik dalam tingkah laku, adab, sopan santun 
serta gaya bicara 2) menjaga hak meliputi hak perlindungan dan perawatan, hak asuh dan kasih sayang, serta hak nafkah dan pemenuhan kebutuhan baik kebutuhan fisik, psikis dan biologis.

Ada beberapa ciri-ciri dalam kepribadian muslim ialah sebagai berikut: 1) beriman yang tangguh, 2) beramal sholeh, 3) berakhlak mulia.

Dan faktor yang menyebabkan pembentukan kepribadian muslim anak yaitu 1) faktor pembawaan, fitrah atau potensi dan 2) faktor lingkungan.

Ada tiga lingkaran yang membentuk karakter manusia; keluarga, sekolah dan masyarakat meski ketiganya saling mempengaruhi tetapi yang paling dominan pengaruhnya adalah pendidikan dalam keluarga, sedangkan peranan yang paling berpengaruh dalam pembentukan kepribadian di lingkungan keluarga adalah orang tua, orang tua merupakan pendidik pertama dan utama bagi anak-anaknya.

Adapun faktor-faktor yang dapat mengokohkan kepribadian muslim anak menurut hamka yaitu: (1) bertujuan. 2) berkeinginan bekerja 3) rasa wajib. 4) pengaruh shalat 5) pengaruh agama dan iman.

Sedangkan faktor yang bisa melemahkannya adalah: 1) menjadi bayang-bayang dari orang lain. 2) ikatan adat lama. 3) budak kitab. 4) tak tentu arah. Dan 5) benalu.

Anak yang lahir dalam keluarga yang selalu membiasakan berbuat baik, biasanya menghasilkan pribadi anak yang baik. Dan sebaliknya anak yang lahir dalam keadaan keluarga yang selalu membiasakan perbuatan-perbuatan tercela biasanya menghasilkan pribadi anak yang tercela pula.

Kehidupan keluarga merupakan tempat pertama dimana sifatsifat pendidikan anak bertambah dan terbentuk. Seseorang akan menjadi warga masyarakat yang baik sangat tergantung pada 
sifatsifat yang tumbuh dalam kehidupan keluarga dimana anak itu dibesarkan. 


\section{DAFTAR PUSTAKA}

Aisyah W, Dewi. 2001. Sosok Ibu Rumah Tangga Yang Sukses. Surabaya: Putra Belajar

D, Marimba, Ahmad. 1982. Pengantar Filsafat Pendidikan Islam. Bandung: PT. Al- Ma'arif.

Departemen Agama RI. 2005. Al-Qur'an dan Terjemahannya. Jakarta.PT.Syamil cipta karya.

Derajat, Zakiyah. 2003. Ilmu Jiwa Agama. Jakarta: Bulan Bintang.

Hamka. 1989. Menjadi Pribadi muslim sejati. Jakarta: Bulan Bintang.

Husain Toha, Khoiriyah. 1992. Konsep Ibu Teladan. Surabaya: Risalah Gusti.

Ja'far, Muhammadiyah. 1982. Beberapa Aspek Pendidikan Islam. Surabaya: Al- Ikhlas.

Kasiram.1990. Ilmu Jiwa Perkembangan, Surabaya:Usaha Nasional

Ngalim Purwanto. 2000. Ilmu Pendidikan Teoritis Dan Praktis. Bandung: Remaja Rosda Karya.

Suryapratondo Suparlan. 1993. Ilmu Jiwa Kepribadian. Jakarta: Paryu Barokah

Suyono Agus, Lubis Halen, dan Hadi Taufik. 2011. Psikologi Kepribadian. Jakarta: Aksara Baru. 
Suryabrata, Sumadi. 2006. Psikologi Kepribadian. Jakarta: Rajawali pres

Yusuf Bakir, Pasmawi. 1993. Pembinaan

Kehidupan Beragama Islam Pada Anak. Semarang: Dino Utama.

Zaini, Syahriman.1996. Nilai-nilai Iman. Surabaya: Usaha Nasional

Zuhairini dkk. 2011. Filsafat Pendidikan Islam. Jakarta: Bumi Aksara 